\title{
How Should Claims For Religious Exemptions Be Weighed?
}

\author{
Paul Billingham \\ Christ Church, University of Oxford, UK \\ This is an Accepted Manuscript version of an article forthcoming in the Oxford Journal of \\ Law and Religion.
}

\begin{abstract}
Many philosophers and jurists believe that individuals should sometimes be granted religiouslygrounded exemptions from laws or rules. To determine whether an exemption is merited in a particular case, the religious claim must be weighed against the countervailing values that favour the uniform application of the law or rule. This paper develops and applies a framework for assessing the weight of religious claims to exemption, across two dimensions. First, the importance of the burdened religious practice, which is determined by its level of obligatoriness and centrality, according to the beliefs of the individual claimant. Second, the extent of the burden on the practice, which depends on the cost the individual bears if she both undertakes the religious practice and obeys the law or rule, where costs are assessed using an impartial account of individual interests. Exemptions should be granted when claims are weighty on either of these dimensions and the countervailing value is relatively weak. The final section of the paper responds to an important objection to this approach, which concerns administrability.
\end{abstract}

\section{INTRODUCTION}

Many philosophers and jurists endorse an approach to religious exemptions known as 'reasonable accommodation'. On this view, religious individuals have a pro tanto claim to the accommodation of (certain) actions that they desire to undertake for religious reasons, through their being given an exemption from a rule or law imposed by an employer, place of education, or the state. This claim is weighed against the interest that the state (or employer or school) has 
in the uniform application of the rule. Exemptions should be granted whenever the religious claim outweighs these countervailing considerations.

In US jurisprudence, the so-called 'Sherbert test' reflects this view. This test derives from the Supreme Court decision in Sherbert v. Verner ${ }^{1}$ that individuals who refuse Saturday work on the basis of a religious conviction could not be denied unemployment compensation. The doctrinal justification given for this decision was that a law that 'substantially burdens' an individual's exercise of religion can be enforced against her only if the state has a 'compelling interest' in its application that cannot be adequately served by less restrictive means. In cases where there is a 'substantial burden' and no 'compelling state interest', exemptions should be granted.

This approach was strongly challenged by the Supreme Court's ruling in Employment Division v. Smith, ${ }^{2}$ in which Justice Scalia, writing for the majority, declared that the balancing test derived from Sherbert was unworkable. Nonetheless, Sherbert-style tests still apply to US federal laws, through the Religious Freedom Restoration Act (RFRA) (1993) and the Religious Land Use and Institutionalised Persons Act (2000), and such tests are also included in many state constitutions. ${ }^{3}$

This approach can also be seen in recent European jurisprudence. For example, in January 2013 the European Court of Human Rights (ECtHR) released its judgment on four religious exemptions cases involving UK citizens. ${ }^{4}$ In this judgment, the Court explicitly adopted a balancing test, talking about the considerations on 'each side of the scales' that it took into

\footnotetext{
1374 U.S. 398 [1963].

2494 U.S. 872 [1990].

${ }^{3}$ For a detailed account of this history, see Kent Greenawalt, Religion and the Constitution, Volume 1: Free Exercise and Fairness (Princeton UP 2006) 11-34.

${ }^{4}$ Eweida and others v. United Kingdom [2013] ECtHR 37.
} 
account in reaching its verdicts. ${ }^{5}$ The same was true in the ECtHR's July 2014 judgment on France's ban on face coverings in public places. ${ }^{6}$

One important question for the reasonable accommodation approach is how to determine the weight of a religious claim, or how 'substantial' a burden is. While various accounts have been offered as to the grounding of a right to accommodation, less theoretical attention has been paid to what factors determine the weight of particular claims to exemption. ${ }^{7}$ Ernest Lim has recently highlighted this lacuna, and challenged defenders of religious exemption to provide a principled and workable theory of how legislatures and courts can establish when exemptions ought to be granted, by articulating clearer standards for use within the balancing test. ${ }^{8}$ This paper responds to that challenge by developing an account of how the weight of a claim to exemption ought to be determined. The legitimacy of religious accommodation in general is taken as given here, in order to focus on this question of weight. ${ }^{9}$

\footnotetext{
${ }^{5}$ For example, see para 94.

${ }^{6}$ S.A.S. v. France [2014] ECtHR 695.

${ }^{7}$ For recent accounts of grounding, see Paul Bou-Habib, 'A Theory of Religious Accommodation' (2006)

23(1) Journal of Applied Philosophy 109-126; Jocelyn Maclure and Charles Taylor, Secularism and Freedom of Conscience (Harvard UP 2011); Yossi Nehushtan, 'What Are Conscientious Objections Really About?' (2013) 2(2) Oxford Journal of Law and Religion 393-416; Martha Nussbaum, Liberty of Conscience: In Defense of America's Tradition of Religious Equality (Basic Books 2008); Jonathan Quong, 'Cultural Exemptions, Expensive Tastes, and Equal Opportunities' (2006) 23(1) Journal of Applied Philosophy 53-71; Kevin Vallier, 'The Moral Basis of Religious Exemptions' (2016) 35(1) Law and Philosophy 1-28.

${ }^{8}$ Ernest Lim, 'Religious Exemptions in England' (2014) 3(3) Oxford Journal of Law and Religion 440-461. 9 This is not to say that the grounding and weighing questions are entirely distinct, merely that we can make progress on the latter without having a settled view on the former. A third set of questions, beyond grounding and weighing, concern who should actually make decisions about exemptions (i.e. legislatures or courts) and how the regime of exemptions should be structured. These questions are beyond the scope
} 
Kent Greenawalt states that “a test of 'substantial burden' turns on the importance of the burdened practice and the extent to which it is burdened." 10 Greenawalt here identifies two distinct dimensions on which we can weigh religious claims. This paper analyses these dimensions in turn. On the first dimension, I argue that the importance of a burdened practice is determined by its level of obligatoriness and centrality, according to the beliefs and values of the individual claimant. On the second dimension, I argue that we can measure the extent of the burden by assessing the cost that the individual bears if she both undertakes the religious practice and obeys the law or rule (assuming that such a combination of acts is possible), where costs are assessed using an impartial account of individual interests.

These arguments establish a framework for judging the weight of religious accommodation claims. To determine whether an exemption is merited in a particular case, the religious claim must be weighed against the relevant 'state interest', or countervailing values. Considering this aspect of reasonable accommodation is beyond the scope of this paper. I will, however, argue that if a burden is weighty on either of the two dimensions and the competing value is relatively weak, then an exemption should be granted.

The final section of the paper responds to an important objection to the approach developed here: that it could not be fairly administered by courts.

\section{PRELIMINARIES}

Before turning to the main argument, two preliminary comments are required.

First, this paper is agnostic on the question of whether religion is in some way 'special', such that exemptions are warranted in light of individuals' religious beliefs in a way that they

of this paper. For helpful discussion, see Yossi Nehushtan, 'The Case for a General Constitutional Right to be Granted Conscientious Exemption' (2016) 5(2) Oxford Journal of Law and Religion 230-254.

10 Greenawalt (n 3) 205. 
are not for other conscientious moral beliefs. ${ }^{11} \mathrm{~A}$ growing number of theorists have argued that religion is not special, and that the correct account of reasonable accommodation will apply to non-religious moral beliefs in the same way as it applies to religious beliefs. ${ }^{12}$ This might well be correct. Many of the most plausible groundings of reasonable accommodation - such as appeals to the value of conscience and the importance of ethical integrity - naturally extend to nonreligious beliefs.

This paper focuses on religion because this is also the focus of much of the existing literature, and of relevant court cases. Some of the considerations that determine the weight of exemption claims are more easily evaluated for religiously-based claims, so the extension of reasonable accommodation to non-religious beliefs might raise new problems and questions. Nonetheless, if the general approach defended in this paper is sound then it should also apply to non-religious exemption claims, even if some modifications are required.

Second, it is possible to understand Sherbert-style tests in two distinct ways. The first of these, which we can call the 'threshold approach', sees the first part of the test as asking whether a religious practice faces a burden that reaches the level of being 'substantial'. If it does, then we proceed to the second part of the test and ask whether the state (or employer) interest in the uniform application of the law (or rule) is 'compelling'. If it is, then no exemption is granted; if it is not, then the exemption is granted. On this interpretation, there is no weighing of the religious claim against the state interest. There is a pro tanto case for an exemption whenever there is a 'substantial burden', and that case is then overridden if there is a 'compelling state interest'. This is true no matter how substantial the burden is, or how compelling the state interest is.

\footnotetext{
${ }^{11}$ For an excellent overview of the debate on this question, see Gemma Cornelissen, 'Belief-Based Exemptions: Are Religious Beliefs Special?' (2012) 25(1) Ratio Juris 85-109.

${ }^{12}$ See Nussbaum (n 7) pp. 168-174; Maclure and Taylor (n 7) 89-91; Michael J. Perry 'From Religious Freedom to Moral Freedom' (2010) 47(4) San Diego Law Review 993-1013.
} 
The arguments in this paper assume a different interpretation, the 'weighing approach'. According to this view, we first establish how substantial a burden there is to religious practice, and then weigh this against the countervailing considerations in favour of the uniform application of the law. Thus, even if there is a somewhat compelling state interest, an exemption might still be merited if a religious practice is very substantially burdened.

The weighing approach is much more plausible than the threshold approach. Consider the comparison between a Sikh claiming an exemption based on the religious requirement that he wears a turban at all times and a Christian claiming an exemption based on her religiouslymotivated desire to wear a cross necklace as a witness to her faith. Intuitively, the former claim appears weightier. Being prevented from wearing his turban is a more substantial burden upon the Sikh's religious practice than is the Christian being prevented from wearing her necklace. Nonetheless, both types of claim could be substantial enough that there is a pro tanto case for an exemption. The threshold approach in effect considers both claims to have the same weight, such that both are defeated if there is a countervailing compelling state interest. Instead, however, we should recognise that the Sikh's claim is weightier, such that it can withstand stronger countervailing values. The weighing approach allows us to do this.

The threshold approach better fits with the phrasing of the test stated in the Sherbert ruling, and of subsequent versions of the test. In practice, however, courts in both the USA and Europe have followed the weighing approach. As Greenawalt notes, "in reality, courts consider burden in light of government interest and government interest in light of burden, striking a kind of balance." 13 Courts take into account the weight of the religious claim when considering whether the burden is justified, or 'proportional'.14 They do not view all substantial burdens as equally substantial.

\footnotetext{
13 Greenawalt (n 3) 202. See also 214.

14 'Proportional' is the term used by the ECtHR.
} 
This was explicitly acknowledged by Chief Judge Posner in his opinion in Mack v. O'Leary. ${ }^{15}$ Posner stated that "the less central an observance is to the religion in question the less the officials must do"16 to accommodate it. In cases where the religious claim is less weighty, a less compelling state interest is needed to justify the lack of exemption. When the religious claim is weightier, stronger countervailing considerations would be needed to overcome the pro tanto claim to an exemption. This is something that the threshold approach cannot accommodate.

The threshold approach still raises the question of how we determine whether a religious claim is 'substantial'. An account is still needed of what criteria a claim must meet in order to reach this threshold, so the question discussed in this paper is still relevant. But once the threshold is met, all religious claims are assigned the same weight.

In my view, it is much better to have criteria that establish not just whether a claim is substantial, but also how substantial it is. This allows us to weigh religious claims against countervailing state interests. It is also worth highlighting that the weighing approach matches the view that many scholars hold concerning constitutional rights adjudication more generally. As Grégoire Webber has noted, the discourse and practice of balancing, or proportionality, is the 'received approach' in this area. ${ }^{17}$ Theorists such as Robert Alexy have developed sophisticated accounts of what this involves. In a nutshell, Alexy holds that interference with a constitutional rights principle must be shown to be necessary to serve a constitutionally valid purpose, and the importance of serving that purpose must be sufficient to justify the intensity of the

\footnotetext{
1580 F.3d 1175 [7th Cir., 1996]. See below (p. 32) for further discussion of this case.

16 ibid para 15.

${ }^{17}$ Grégoire C.N. Webber, 'Proportionality, Balancing, and the Cult of Constitutional Rights Scholarship' (2010) 23(1) Canadian Journal of Law and Jurisprudence 179-202. Webber is highly critical of balancing, but I believe that the approach taken in this paper, which makes explicit the moral judgments involved in weighing religious exemptions, evades his most telling objections.
} 
interference, in the particular circumstances of the case. ${ }^{18}$ When this condition is not satisfied, the interference is disproportionate, and is thus prohibited. The weighing approach to reasonable accommodation applies this kind of account to the specific area of interferences with freedom of religion.

The rest of this paper develops and defends a framework for determining the weight of religious claims, across the two dimensions identified by Greenawalt. In Alexy's terms, it offers an approach to establishing the intensity of the interference with freedom of religion. 19

\section{THE FIRST DIMENSION - THE IMPORTANCE OF THE BURDENED PRACTICE}

\section{A. Obligatoriness and Centrality}

The first dimension concerns the level of importance that the restricted practice has within the individual's faith. As John Garvey notes, the acts relevant to religious accommodation "vary... greatly in their importance to the claimant... Belief or conduct may be commanded, recommended, rewarded, encouraged, desired, permitted, discouraged, forbidden, or punished within a claimant's belief system."20 This makes a difference to the weight of religious claims.

As was noted above, intuitively a Sikh's claim to be able to wear a turban, which is a strict obligation within orthodox Sikhism, seems weightier than a Christian's claim to be able to wear a cross necklace, which some Christians see as a helpful way of manifesting their commitment to Christ, but none see as a requirement of the faith. One obvious and important difference here is that the former religious practice is obligatory, while the latter is not. The Sikh would consider himself to be violating a religiously-grounded moral obligation if he did not

\footnotetext{
${ }^{18}$ See Robert Alexy, A Theory of Constitutional Rights (OUP 2010), 44-110, 388-425.

${ }^{19}$ See ibid 401-402.

${ }^{20}$ John H. Garvey, 'Free Exercise and the Values of Religious Liberty' (1986) 18(4) Connecticut Law Review 789-802, at 685. Garvey adds that "it would be irrational for the law to ignore those differences in deciding what social costs to tolerate in the interest of accommodation," and so explicitly endorses the weighing approach.
} 
wear the turban. To not wear the turban would be to act wrongly. This is not the case for the Christian. She might well feel aggrieved if she was not able to wear the necklace, and believe that this stops her from fully living out her faith and weakens her public witness. But she would not believe that she is acting wrongly. She is not violating a moral obligation, even if she is prevented from doing what she believes is best.

Some theorists have argued that exemptions can only be warranted when a religious obligation is at stake. It is only in such cases that a burden is 'substantial'. ${ }^{21}$ Courts have also sometimes appealed to this idea, such as in the case of Nancy Eweida, a British Airways employee who wanted to wear a small silver cross over her uniform. This contravened British Airways' uniform code, which required that employees wore no visible jewellery, ${ }^{22}$ and led to Eweida being sent home without pay until she agreed to comply with the uniform code. ${ }^{23}$ The Employment Tribunal rejected her claim of religious discrimination, and explicitly based its decision, in part, on the fact that wearing a cross was not a requirement of Christianity. ${ }^{24}$ It was a personal preference on her part, rather than a doctrine of her faith. The Court of Appeal also cited this fact, in upholding the Employment Tribunal's ruling. ${ }^{25}$ When this case came before the ECtHR, the UK Government argued that the wearing of a visible cross "was not a recognised religious practice or requirement of Christianity," 26 and therefore was not covered by Article 9 of the European Convention of Human Rights, which concerns freedom of religion.

While the distinction between obligatory and non-obligatory practices is important, an exclusive focus upon it is too narrow. Religious practices can be central to an individual's faith,

\footnotetext{
${ }^{21}$ For example, Bou-Habib (n 7). This is due to his overly-narrow definition of 'integrity'.

${ }^{22}$ Religious exceptions to this were permitted, but only for obligatory religious jewellery.

${ }^{23}$ The code was eventually changed, such that non-obligatory religious jewellery was permitted. Eweida returned to work, but claimed compensation for lost earnings during the time of her suspension.

24 This is noted by Russell Sandberg, 'Eweida v British Airways’ (2008) 160 Law and Justice 56-59, at 58.

${ }^{25}$ Eweida v. British Airways PLC [2010] EWCA Civ 80. See paras 34 and 37.

${ }^{26}$ Eweida and others (n 4) para 58.
} 
and to her expression of that faith, without being obligatory. Such practices give rise to weighty claims for accommodation, because they are vital to the individual's moral and religious identity. Many practices that are not mandatory are nonetheless very important to their practitioners, who would consider the denial of them a grave curtailment of their religious liberty. ${ }^{27}$

This could be the case for a Christian's wearing of a cross. Indeed, the ECtHR eventually found in Eweida's favour. They considered her desire to manifest her religious beliefs and to be able to communicate those beliefs to others to be central to her religious practice, and recognised that visibly wearing a cross was a way for her to do this. As Julie Maher writes, this ECtHR judgment is important because it indicates that within European law "the question of whether an act qualifies as a manifestation cannot be interpreted as a requirement that the applicant establish that they were fulfilling a duty mandated by their religion."28

The ECtHR nonetheless argued that "in order to count as a 'manifestation' within the meaning of Article 9, the act in question must be intimately linked to the religion or belief." There must be "a sufficiently close and direct nexus between the act and the underlying belief." Thus, acts "which do not directly express the belief concerned or which are only remotely connected to a precept of faith" are not protected. ${ }^{29}$ In other words, the burdened religious practice does need to be somewhat central to the individual's faith in order to ground a claim for an exemption, but it need not be mandatory.

This approach can also be seen in US jurisprudence. Greenawalt notes that a number of US courts applying the 'substantial burden' language of the RFRA "have asked whether practices that are impaired are mandatory or optional, or are central or not central."30

\footnotetext{
${ }^{27}$ As Posner notes in Mack (n 15) para 10.

${ }^{28}$ Julie Maher, 'Eweida and Others: A New Era for Article 9?' (2014) 63(1) International and Comparative Law Quarterly 213-233, at 221.

${ }^{29}$ All the foregoing quotes are from Eweida and others (n 4) para 82.

${ }^{30}$ Greenawalt (n 3) 204.
} 
The weightiest claims, on this first dimension, will indeed be ones based on a religious obligation. But claims based on a practice that is central to an individual's faith can also be very weighty. Both obligatoriness and centrality should be taken into account in determining the first-dimension weight of a religious claim. A claim is weightier the more obligatory and/or central the relevant practice is.

Greenawalt rejects this focus on ideas of centrality and obligatoriness. ${ }^{31} \mathrm{He}$ argues that there are some cases where a practice is neither mandatory nor central yet weighty accommodation claims could nonetheless arise. For example, hymn-singing is not a central or mandatory part of the Christian faith, yet a ban on singing would be a substantial burden on religious practice. In other cases, an infringement of a central and mandatory practice does not impose a substantial burden. Practices that are both obligatory and central can be restricted without this leading to weighty exemption claims. For example, communion is mandatory and central within Christianity, but a ban on wine is not a substantial burden, because grape juice can be used instead. For Greenawalt, these examples show that ideas of centrality and obligatoriness do not adequately capture the importance of a religious practice.

Far from acting as counterexamples, Greenawalt's examples actually support the view defended here. Greenawalt is right that hymn-singing is not mandatory within Christianity; Christians do not believe that they violate moral obligations by not singing. But hymn-singing is central to Christians' practice of their faith. The Bible explicitly exhorts Christians to sing praise to God, ${ }^{32}$ and singing is an integral part of corporate worship within many Christian traditions. The fact that Greenawalt believes Christians would have weighty claims to exemption shows that centrality matters in determining the importance of a religious practice. This is a case where a burden on a non-obligatory but central practice is substantial.

\footnotetext{
31 ibid.

${ }^{32}$ For example, see Ephesians 5:19 and Colossians 3:16. Singing was also central to the worship of ancient Israel, as the book of Psalms shows (e.g. Psalm 95:2).
} 
If Greenawalt was right about the status of hymn-singing, however, then Christians would not have weighty claims to an exemption from a ban on singing. Our intuition that such a ban would be wrong is instead being driven by the fact that we can see no government interest being served by it. Even if religious claims against the ban would be fairly weak, they would be strong enough to defeat the ban because of the lack of a government interest. Indeed, in this case the lack of government interest shows that there simply should be no such law. In some situations where there seems to be a case for an exemption, this really shows that the law itself should be repealed.33 If there was a compelling government interest here, for example if a ban on singing was somehow important for national security reasons, then there would not be a strong case for a religious exemption, assuming that hymn-singing is neither obligatory nor central.

With regard to communion, Greenawalt's argument works by misdescription. He argues that a ban on wine would not substantially burden religious exercise, despite communion being central and mandatory, because grape juice can be used instead. But this simply shows that while 'communion' is central and mandatory, 'communion using wine' is not. The act that is actually prohibited - drinking wine - is neither central nor mandatory and that is why the ban would not give rise to weighty exemption claims. A ban on communion itself, using any drink, in contrast, would give rise to such claims, precisely because communion is a central and mandatory part of the Christian faith. Similarly, if some Christian denominations believed that communion must in fact use wine, such that grape juice was not a permissible substitute, then a ban on wine would constitute a substantial burden.

While some theorists would see the account defended here as too capacious, and want to limit legitimate exemption claims to cases of religious obligation, others would make the opposite objection. According to Nick Spencer, we should not investigate the importance of religious practices at all. He argues that what matters is simply good-faith assertions of religious

\footnotetext{
${ }^{33}$ See Brian Barry, Culture and Equality: An Egalitarian Critique of Multiculturalism (Polity Press 2011) 40-50; Vallier (n 7).
} 
belief, not their level of significance to the believer. ${ }^{34}$ One reason for this is that a focus on the importance of a practice can lead to legal imbalances. Spencer claims that this can be seen by comparing the cases of Lydia Playfoot ${ }^{35}$ and Sakira Watkins-Singh, ${ }^{36}$ both of whom requested exemptions from school uniform rules in order to wear religious jewellery - a chastity ring in Playfoot's case, and a kara bracelet in Watkins-Singh's case. Spencer argues that these cases are substantially similar. Neither piece of jewellery is especially evident on the wearer, constitutes a health risk, or offends public opinion, and both clearly symbolise something of real importance to the wearer. Yet Playfoot lost her case, on the grounds that wearing the purity ring was neither obligatory nor central to her Christian faith. In contrast, Watkins-Singh won, because she considered the kara an "extremely important indication of her faith... a view shared for good reason by very many other Sikhs." 37 While wearing the kara is not strictly obligatory for Sikhs, it is one of the five outward signs of faith that act as important identifiers of the religion. ${ }^{38}$ Spencer claims that the courts' insistence on judging what is and is not intimately linked to religious belief led to an imbalance of justice. The cases were substantially similar, so the same judgment should have been reached in each.

Contra Spencer, this claimed 'legal imbalance' in fact shows the courts being rightly sensitive to the importance of the relevant practice. Watkins-Singh had a stronger claim to an exemption precisely because the burdened practice was more central to her faith. This is not to say that the ruling in Playfoot's case was necessarily correct. The fact that the relevant religious practice was less important to her does not in itself mean that she should have lost her case,

\footnotetext{
${ }^{34}$ Nick Spencer, How to Think About Religious Freedom (Theos 2014) 61. Greenawalt (n 3) 207 claims that this kind of 'sincere motivation' view clearly sets the bar too low.

35 Playfoot (a minor), R (on the application of) v. Millais School [2007] EWHC 1698 (Admin).

${ }^{36} R$ (on the application of Sarika Angel Watkins-Singh) v. The Governing Body of Aberdare Girls' High School [2008] EWHC 1865 (Admin).

37 ibid para 29.

${ }^{38}$ The 'five Ks', which also include the kirpan, discussed below.
} 
since claims that are relatively weak on this first dimension can still merit exemptions if they are strong on the second dimension and the competing value is weak. But her claim was certainly weaker than Watkins-Singh's, on this first dimension, precisely because the practice concerned was less central. It is implausible to see all good-faith assertions of religious belief as having the same weight, as Spencer demands.

Further, it is not clear that Spencer's approach would actually lead to religious exercise being better protected, in the way he desires. If we see all good-faith assertions of religious belief as having the same weight, and so the same level of pro tanto claim to an exemption, then we will have to set the bar for a 'compelling state interest' fairly low, in order to avoid a huge proliferation of exemptions. Claims that should be recognised as very weighty, such that they outweigh even strong countervailing values, would not be seen as such, and would thus be rejected even when the countervailing values are relatively weak. This again shows that the threshold approach fails to make necessary distinctions.

\section{B. Measuring Importance}

If the importance of a religious practice is determined by its obligatoriness and centrality then this raises the question of how we judge these things. On what basis can we conclude that a particular practice is (or is not) obligatory or central to an individual's faith?

One option is to examine the place of the practice within the canons of the relevant faith. We could consult Scripture, theologians, and religious leaders, in order to identify the orthodox belief about the obligatoriness and importance of the practice, and to ascertain what proportion of adherents engage in this practice. Courts have sometimes done this. ${ }^{39}$ For example, the Employment Appeal Tribunal stated that Eweida's appeal failed because there was "no evidence that a sufficient number of persons other than the claimant shared her strong religious view

\footnotetext{
${ }^{39}$ For further discussion of the approach of UK courts to analysing the centrality of beliefs, see Lim (n 8), 450-454.
} 
that she should be allowed visibly to wear the cross." 40 Eweida's claim was judged to be weak because most Christians do not consider it important to visibly wear a cross. ${ }^{41}$ This fact was also central to the Court of Appeal's ruling, and the UK Government again appealed to it at the ECtHR, arguing that behaviour that "was not an act of practice of a religion in a generally recognised form, fell outside the protection of Article 9." ${ }^{\prime 2}$

Theorists and judges have articulated two good reasons to be wary of this approach. First, we do not want courts to adjudicate on complex questions of theological interpretation, especially since there is a great deal of disagreement among religious communities. It is not up to courts to resolve disagreements about the content of a religion, and they are ill-placed to do so. As Greenawalt argues, courts must avoid deciding what is really important religiously or judging "which among competing versions of a practice represents a correct understanding of a religious tradition. Courts must take claims as they are sincerely presented by those who seek an exemption."43

${ }^{40}$ Eweida v. British Airways Plc [2008] UKEAT 0123_08_2011, para 77.

${ }^{41}$ There is slight complication here. The Tribunal and Court of Appeal were ruling on whether Eweida had suffered indirect discrimination, rather than whether her Article 9 rights had been infringed. Both courts ruled that indirect discrimination only occurs if there is an 'identifiable group' that suffers it. Hence their appeal to the beliefs of 'most Christians'. However, the fact that Eweida could not appeal to Article 9 directly was due to controversial previous jurisprudence (in particular $R$ (on the application of Begum) $v$. Denbigh High School Governors [2006] UKHL 15), which meant that Article 9 rights were insufficiently protected in UK law - as the ECtHR ultimately ruled. Further, the claim that indirect discrimination only occurs when there is an 'identifiable group' suffering it is itself controversial, as is the identification of the relevant group. For discussion, see Nicholas Hatzis, 'Personal Religious Beliefs in the Workplace: How Not to Define Indirect Discrimination' (2011) 7(2) The Modern Law Review 287-305.

${ }^{42}$ Eweida and others (n 4) para 58.

${ }^{43}$ Greenawalt (n 3) 205. See also Maclure and Taylor (n 7) 81-84. 
The US Supreme Court has repeatedly emphasised this. ${ }^{44}$ For example, in Thomas $v$. Review Board of the Indiana Employment Security Division, ${ }^{45}$ Chief Justice Burger wrote that "it is not within the judicial function and judicial competence to inquire whether the petitioner or his fellow worker more correctly perceived the commands of their common faith. Courts are not arbiters of scriptural interpretation." 46

In the UK, Lord Nicholls made the same argument in his judgment in $R$ (Williamson and others) v. Secretary of State for Education and Employment. ${ }^{47}$ He wrote that

"emphatically, it is not for the court to embark on an inquiry into the asserted belief and judge its 'validity' by some objective standard such as the source material upon which the claimant founds his belief or the orthodox teaching of the religion in question or the extent to which the claimant's belief conforms to or differs from the views of others professing the same religion." 48

The second, and more important, reason to be wary of assessing the strength of religious claims based on the orthodox teachings of the relevant religion is that liberals ground exemptions in individual freedom of conscience and religion. While liberal theorists disagree on the precise grounding for reasonable accommodation, they all agree that it is based on respect for individuals. As Lord Nicholls puts it, "freedom of religion protects the subjective belief of an individual." 49

Lord Neuberger stated this very clearly when considering a Hindu's claim to have his body burnt on an open air funeral pyre, writing that "what we are concerned with in this case is, of course, what Mr Ghai's belief involves when it comes to cremation, and it matters not for present purposes whether it is a universal, orthodox or unusual belief for a Hindu."50

\footnotetext{
${ }^{44}$ Indeed, Greenawalt states that it is part of US constitutional law. Greenawalt (n 3) 28.

45450 US 707 [1981].

46 ibid 716.

47 [2005] UKHL 15.

48 ibid para 22.

49 ibid.

${ }^{50}$ Ghai, R (on the application of) v. Newcastle City Council \& Ors [2010] EWCA Civ 59, para 19.
} 
The obligatoriness and centrality of a burdened religious practice should therefore be determined by examining the place of that practice within the claimant's system of beliefs and values, or belief-value set. As Maclure and Taylor put it, the "special legal status of religious beliefs is derived from the role they play in people's moral lives." 51 What matters is what the claimant believes about the practice (whether it is religiously obligatory, recommended, or merely desirable), how central it is to her religious and moral identity, and the place that it has within her lifestyle and actions. It is therefore up to the claimant to demonstrate the importance of the practice to her. She should explain her beliefs about it, and the reasons that she holds those beliefs, and show that she puts those beliefs into practice in how she lives.

Judgments of sincerity are important here. A common part of courts' approach to accommodation cases is seeking to determine whether the claimant's expressed views about the relevant practice are sincere. 52 For example, does an applicant for conscientious objector status honestly believe that Jesus' encouragement to turn the other cheek enjoins Christians to be pacifists? Searching inquiries into sincerity are often troubling for the individual concerned. It is unpleasant to have one's honesty challenged and one's claimed beliefs cross-examined. Nonetheless, such an investigation is necessary in order to determine the weight of the religious claim.

One obvious part of investigating sincerity is checking whether the claimant has lived by the belief they profess. If a case is based on a Sabbatarian's belief that they must not work on the Sabbath and yet there is clear evidence that they have often undertaken such work, then this counts against their claim. ${ }^{53}$ Courts should also consider whether the claimant would gain any

\footnotetext{
${ }^{51}$ Maclure and Taylor (n 7) 81.

${ }^{52}$ For discussion, see Greenawalt (n 3) 109-123.

${ }^{53} \mathrm{~A}$ real-life example along these lines involved Hasanali Khoja, a Muslim chef who lost a discrimination case against the Metropolitan Police. He had claimed religious discrimination after being forced to cook pork products, but a witness testified that she had recently served him bacon rolls. See Tom Harper, 'Muslim Police Chef Defeated in 'Bacon Roll' Tribunal Faces £75,000 Legal Bill', Mail Online, 20th
} 
obvious secular benefit from being granted an exemption. ${ }^{54}$ If they would not, then less evidence is required to establish sincerity than if there is a clear motivation for dishonesty due to the available secular gain.

Another vital piece of evidence for determining the likely place of the practice within the claimant's religious beliefs, and for judging the sincerity of her claim, is the views and practices of her co-religionists. 55 The 'orthodox' or 'common' views within a religion do not determine the weight of an individual's claim. Nonetheless, they do provide helpful evidence as to both its weight and sincerity. If I claim that I must perform action $X$ because I am a Methodist, then the fact that no other Methodists believe $X$ to be obligatory can rightly be taken to cast doubt on my claim. On the other hand, if a Sikh claims that he is obligated to wear a turban or to carry a kirpan then the fact that these are religious requirements within orthodox Sikhism provides strong evidence in favour of his claim being both sincere and weighty. Indeed, in this case the evidence is likely decisive, as long as there is no reason to doubt that the claimant is a practising Sikh.

This can be seen in the ECtHR's judgment on France's ban on face coverings in public places. The Court noted that "there is no doubt" that wearing the full-face veil "is, for certain Muslim women, a form of practical observance of their religion."56 For this reason, the Court felt no need to examine or question the particular claimant's statements about the importance of the full-face veil to her. The fact that a significant minority of Muslim women considered this a

December 2009, available at http://www.dailymail.co.uk/news/article-1237184/Muslim-police-chefdefeated-bacon-roll-tribunal-faces-75-000-legal-bill.html.

54 This point is taken from Greenawalt (n 3) 122-123.

55 This observation helps to defuse some of the worries concerning assessments of 'subjective authenticity' raised by Avigail Eisenberg, 'What is Wrong with a Liberal Assessment of Religious Authenticity?', in Geoffrey Brahm Levey (ed), Authenticity, Autonomy and Multiculturalism (Routledge 2015) 145-162.

56 S.A.S. (n 6) para 56. 
requirement of their faith was sufficient to establish that the particular claimant had a claim under Article 9. Similarly, Lord Nicholls, immediately after he argued in his Williamson ruling that what mattered was the subjective belief of individuals, added that "objective factors such as source material" may "throw light on whether the professed belief is genuinely held."57

Looking to the views of the claimant's co-religionists in this way gives proper recognition to the communal nature of faith. Religion is usually corporate and communitybased, not merely an individualistic activity. The traditions of scriptural interpretation, belief, and practice within a religion usually matter greatly to individual adherents. This does not mean that those traditions are determinative of the weight of an individual's claim; they are not. But it does mean that they are vital evidence as to the likely place of a particular practice within the claimant's moral life. As Greenawalt puts it, "judges may look to standard doctrines in order to understand the individual claims or to test their sincerity, but the claimants' own honest perceptions should usually be the final determinant." 58 The difference between the view developed here and that of Greenawalt and Nicholls is that I explicitly hold that the 'standard doctrines' of the relevant religion can illuminate the weight of a religious claim, on the dimension of its importance to the claimant, rather than merely throwing light on its sincerity or genuineness as a religious claim.

Of course, this means that courts will be drawn into some theological adjudication and interpretation. This is unavoidable. ${ }^{59}$ It is better to accept this and to allow it to a limited extent than to deprive courts of a major way of assessing the place of the claimant's practice and the sincerity of their claim. Understanding the orthodox position within the claimant's religion does not settle the weight of her particular claim, but it is an essential step in making this determination. It is objectionable for courts to judge the validity of a claim based on such theological investigation, or to dismiss a claim simply because most adherents to the religion in

\footnotetext{
57 Williamson (n 47) para 22.

58 Greenawalt (n 3) 206.

${ }^{59}$ On this point, I agree with Eisenberg (n 55) and Lim (n 8).
} 
question do not share the claimant's view of the practice. But such factors can play a helpful evidential role.

This approach does not rule out unorthodox theological interpretations, or the claims of individualistic or idiosyncratic religious believers. If an individual can demonstrate the central place that a practice has within her beliefs and values, and the role that it plays within her life, then courts should consider her claim to be weighty even if it is idiosyncratic. It is undoubtedly harder to show that an idiosyncratic claim has great weight, since one cannot point to the traditions of belief within one's religion as evidence. But this does not make is impossible.

To summarise, I have argued that the first dimension that determines the weight of a religious claim for an exemption is the importance of the relevant practice to the individual claimant. This importance is determined by how obligatory she believes the practice to be, and how central it is to her moral life.

\section{THE SECOND DIMENSION - THE EXTENT OF THE BURDEN}

The second dimension on which religious exemption claims can be weighed is the extent of the burden placed on the relevant religious practice. In other words, this dimension concerns the extent of the conflict between the religious practice and the law or rule. An 'outright conflict' occurs when the law directly proscribes the practice, such that it is impossible to both obey the law and do the act that one is religiously motivated to perform. This is rare, however. ${ }^{60}$ In most cases, the individual can both obey the law or rule and follow their religion, but the relevant practice is 'burdened' because the law or rule makes it in some way costly to perform. We should determine the extent of the conflict (and so of the burden) by measuring the cost that the individual bears if she both obeys the law or rule and follows her religious practice.

\footnotetext{
${ }^{60} \mathrm{~A}$ ban on peyote - the issue in the Smith case - is an example of an outright conflict, since members of the Native American Church are religiously motivated to ingest peyote.
} 
Three examples will help to illustrate this. First, consider a law requiring everyone to wear helmets when riding motorcycles. The (second-dimension) cost of this to Sikhs is never riding motorcycles, since they believe they are religiously obligated to always wear a turban, and it is not possible to wear both a turban and a motorcycle helmet (we assume). There is no outright conflict here, because neither the law nor their religion requires Sikhs to ride motorcycles. It is possible for Sikhs to fulfil both their religious and legal obligations. But the only way they can do so is by never riding motorcycles. Second, consider a law banning the carrying of all daggers in public places. The cost that this law imposes upon Sikhs is that they can never be in public places. Sikhs believe that they must always carry their kirpan - a ceremonial dagger. Thus, the only way they can both obey this law and follow their religious beliefs is by never being in public places. Third, in cases involving uniform rules or rules on time of work imposed by an employer, the cost to individuals for whom the rule conflicts with a religious practice is losing their jobs.

This second dimension thus measures the 'secular' cost that the individual bears if the exemption is not granted and the individual continues to follow her religious practice, consistent with the law or rule. The first dimension, in contrast, measured the 'religious' cost that the individual bears if the law or rule causes her not to follow the religious practice.

Understanding the extent of the burden in this way allows us to weigh religious claims along this second dimension. The weightiest claims will be those involving outright conflicts. In the more common cases, however, we can make judgments about the strength of the claim based on the level of cost borne by the individual if they obey both the law or rule and their religion.

The question, therefore, is how we measure these costs. It seems intuitive that the cost to Sikhs of an exceptionless law against daggers is higher than the cost of an exceptionless law requiring that riders of motorcycles wear helmets. Not being able to be in public places is a higher cost than not being able to ride motorcycles. This intuition is presumably based on some (implicit) account of individuals' interests. Riding motorcycles is not as essential a human 
interest as being able to be in public places. This suggests an 'objective' approach to the measurement of costs. Costs are higher when more basic interests are at stake, according to an impartial account of human interests, and when those interests are more affected. The more an individual's interests are set back, the higher the burden they bear from being denied an exemption.

Some might propose that the claimant's subjective judgment of cost should also be taken into account. Some Sikhs might really enjoy riding motorcycles, such that an inability to do so (without acting against their religious beliefs) appears to them to be a very high cost. Whereas others might not have any desire to ride, such that they do not consider it much of a cost at all.

This subjective approach should be rejected. While the claimant's subjective beliefs and values determine the weight of their claim on the first dimension, on this second dimension what matters is costs to their interests as measured by an impartial theory. The cost of the law against riding motorcycles without a helmet is thus the same for two orthodox Sikhs (all other things equal), ${ }^{61}$ even if one has a much greater desire to ride. There are several reasons to reject the subjective approach on this second dimension.

First, the subjective approach requires courts to work out how much of a cost the individual feels they bear from both obeying the law and acting on their religious beliefs. This is very difficult to do. It is unclear how courts can determine the strength of individuals' feelings or how much of a burden they feel they bear.

A critic might argue that the same is true with regard to working out the obligatoriness or centrality of the practice for the individual. But this does not seem nearly so difficult. Individuals can state their beliefs and their reasons for their beliefs, in order to show the role the practice plays within their belief-value set and their moral life. Ways in which courts can determine the importance of the practice to the individual (including their sincerity) were suggested above. It is much less clear how a court could work out how much of a cost someone

${ }^{61}$ The contextual factors noted below could make other things unequal. 
feels or how much an individual is upset by bearing the relevant cost. It is especially unclear how this could be done in a way that allows for comparisons to be made across different cases.

Second, the individual's perception of cost is not relevant here anyway. It is important to remember that the cost we are seeking to measure is not the cost of failing to act on one's religious beliefs. That cost is covered by the first dimension, since it will vary depending on how important the practice is. On this second dimension, we are measuring the cost that individuals bear when they do act on their religious beliefs, but consistent with the law. The fact that some Sikhs really like riding motorcycles is simply not relevant to how much the law burdens their religious exercise, since riding motorcycles is not the thing that is religiously mandated wearing a turban is. We are measuring the cost of following the law consistently with one's religious beliefs because it serves as a proxy for the extent to which the law conflicts with one's religion. How one feels about that cost is not the relevant thing here; the relevant thing is an objective judgment of the importance of the interests involved and the extent to which they are set back.

Third, in cases where it does seem like the individual's perception of cost is relevant, this relevance will already have been taken into account on the first dimension. For example, Watkins-Singh might well have felt more upset by her school's uniform rules than Playfoot did about hers. But that is because of a difference on the first dimension - the fact that the rules conflicted with a more important religious practice in Watkins-Singh's case. This makes her claim weightier on the first dimension, and means that she bears a greater cost if she does not follow her religious practice. On the second dimension, they both faced a similar cost. If they wished to wear their religious jewellery then they would have to find an alternative school that permitted them to do so. It is this cost of leaving their current school and finding a different school that matters on the second dimension, and this cost should be judged based on an impartial account of individuals' interests, not based on their feelings about it.

Finally, this also means that we are not under any pressure to cater for every individual who feels put out by a law. Some individuals might very much enjoy feeling the wind blowing 
through their hair when they ride their motorcycles, such that they dislike the law requiring that they wear motorcycle helmets. ${ }^{62}$ This alone should not be the basis for an exemption, and my approach does not count it as one, since the individual does not have a religiously (or morally) motivated objection. If we weighed costs on this second dimension based on the individuals' perception of cost, however, then this would make it harder to resist the claim of those who love to feel the wind in their hair, since they can claim a similar feeling of frustration from the law.

Overall, then, courts should determine the extent of the burden on a religious practice by using an impartial theory of individual interests to determine the cost that the individual bears if they both obey the law and act on their religious beliefs. Clearly there are going to be some difficult cases here. I have not offered a fully specified theory of individual interests, and nor do I have one to offer. Nonetheless, we have a fairly good sense of which interests are basic, such that damage to them makes individuals' lives go significantly worse, and which interests are less basic. Many of the judgments involved here are relatively uncontroversial, such as observing that not being able to be in public places is a greater cost to individual interests than not being able to ride motorcycles. More generally, we can follow Jonathan Quong in identifying a set of basic civic opportunities, such as employment in education, and hold that costs are higher when individuals are burdened in their pursuit and enjoyment of these opportunities.63

There is one further complication here, concerning contextual factors. ${ }^{64} \mathrm{~A}$ useful example of the relevance of such factors is laws requiring that hard hats be worn in building

\footnotetext{
62 This example is from Barry (n 33) 47.

${ }^{63}$ Quong (n 7). As Quong notes (71, fns. 45 and 54), this approach has similarities with the capabilities approach developed by Amartya Sen and Martha Nussbaum.

${ }^{64}$ The importance of a range of contextual factors is rightly emphasised by Jonathan Seglow, "Theories of Religious Exemptions', in Gideon Calder and Emanuela Ceva (eds), Diversity in Europe: Dilemmas of Differential Treatment in Theory and Practice (Routledge 2010) 52-64.
} 
sites. ${ }^{65}$ The second-dimension cost to Sikhs from this law is that they cannot be builders. At first glance, this might not seem like a particularly high cost. In reality, however, the construction trade is the largest single source of employment for Sikhs, for historical reasons, so this is a high cost. To say this is not to move to a subjective approach. The relevant factor is that given the context, Sikhs not being able to work in construction puts many livelihoods at risk. This is an objectively high cost to their interests, rather than being anything to do with what Sikhs feel about construction.

Contextual factors can also matter at a more individualised level. If a motorcycle was the only possible form of transportation for an individual, or she had to use motorcycles as part of her job, then not being able to ride motorcycles consistent with her religious beliefs would be a higher cost than it is for someone with easy alternatives.

This final point relates to what is known as the 'free-contract doctrine'. This is the idea that there can be no interference with religious freedom in cases where employees have voluntarily accepted a role that does not accommodate their religious practice. ${ }^{66}$ Religious freedom is protected by the 'right to resign'. Until recently this was a part of ECtHR jurisprudence. Rulings in a series of cases suggested that "no interference with Article 9 arises where an employee is dismissed or faces work-related detriment because of their desire to act in accordance with their religion during working hours."67

This doctrine can be understood as saying that exemption claims by employees to rules imposed by their employers can be rejected because they have no weight on the second dimension. No matter how important the religious practice, the individual has voluntarily accepted the burdens to it, so we should consider there to be no conflict between that practice and the rule.

65 This example is from Barry (n 33) 49.

${ }^{66}$ This doctrine has also been applied to cases involving students at schools and universities.

${ }^{67}$ Maher (n 28) 224. See the summary in Begum (n 41) para 23. 
This doctrine was rejected by the ECtHR in its judgment on the case of Eweida and others, in the following terms:

"Given the importance in a democratic society of freedom of religion, the Court considers that, where an individual complains of a restriction on freedom of religion in the workplace, rather than holding that the possibility of changing job would negate any interference with the right, the better approach would be to weigh that possibility in the overall balance when considering whether or not the restriction was proportionate."68

This is the correct judgment. The fact that an individual has voluntarily taken a job, and could resign, should not mean that their claim is automatically rejected. Changing jobs, and most likely accepting a period of unemployment, is not a trivial matter. Indeed, in many cases, the fact that an individual can only act consistent with their religious beliefs by leaving their jobs should mean that we consider their claim to be weighty on this second dimension.

The grain of truth in the free-contract doctrine is that contextual factors regarding the individual's situation in relation to their employment should be taken into account when measuring their claim on this second dimension. For example, there might be cases where an individual could fairly easily and costlessly change jobs, and this would make their claim less weighty. As Maher argues, we should also distinguish between "situations where an employee was aware of the restrictions upon religious manifestation prior to agreeing to undertake a particular job role and situations where this was not the case." 69 This is relevant in two of the other cases that the ECtHR considered alongside Eweida's..$^{70}$ Lillian Ladele was a registrar at Islington Council who did not want to conduct civil partnerships, due to her religious objections to same-sex relationships. A relevant feature of her case was that she had worked as a registrar before the law concerning civil partnerships was enacted. Thus, as Spencer puts it, "the employment goalposts were moved around her."71 This is in contrast to Gary McFarlane, who was a relationship counsellor working for the charity Relate. He voluntarily undertook Relate's

\footnotetext{
${ }^{68}$ Eweida and others (n 4) para 83.

${ }^{69}$ Maher (n 28) 225.

${ }^{70}$ For details on these cases, see Eweida and others (n 4) paras 23-40.

${ }^{71}$ Spencer (n 34) 66.
} 
postgraduate diploma in psycho-sexual therapy, knowing that he would be required to provide therapy to both same-sex and opposite-sex couples, despite his religiously-grounded discomfort with working on sexual issues with homosexual couples. The fact that McFarlane knowingly and voluntarily placed himself in a position where his religious beliefs would conflict with the requirements of his employment made his case much weaker than Ladele's, on this second dimension. While their employers' rules meant both would have to leave their jobs if they were to act consistently with their religious beliefs, this cost should be judged lower for McFarlane given the circumstances of the case.

\section{PUTTING IT TOGETHER}

Thus far, this paper has sketched a framework that I contend should be used to assess the weight of religious exemption claims, across two dimensions: the obligatoriness and centrality of the religious practice, and the cost to the individual's interests if they follow that practice consistent with the relevant exemption-less law or rule. Some claims are weighty on both dimensions. The Sikh kirpan case is an example. Carrying the kirpan is a religious obligation, and a law against daggers in public places would mean that Sikhs cannot be in such places (consistent with their religious beliefs). Claims can also be weighty on one dimension and comparatively weak on the other. For example, the Sikh motorcycle case is strong on the first dimension but fairly weak on the second. A Christian's desire to wear a cross, meanwhile, is weaker on the first dimension but potentially strong on the second.

In order to determine whether an exemption should be granted, the weight of the religious claim on these two dimensions must be compared with the weight of the countervailing interest or value. The stronger the state or employer's interest in having the law or rule without granting the exemption, the weightier the religious claim needs to be in order for an exemption to be merited. These countervailing factors include both whatever values or interests are being served by the law or rule and the costs that granting the exemption would impose on third parties. In some cases, the countervailing value is so strong that it can never be 
outweighed. An obvious example is the law against child sacrifice. The law against corporal punishment in schools, which was at issue in the Williamson case, is also in this category - as Lord Nicholls rightly concluded. ${ }^{72}$ Usually, however, some weighing of the two sides is needed, in order to determine whether the religious claim outweighs the countervailing interests.

Considering this stage in detail is beyond the scope of this paper. This section will make four brief claims, however. First, and most obviously, the weaker a claim is on one dimension the stronger it will need to be on the other dimension in order to merit an exemption.

Second, religious exemptions are never warranted if the claim is not reasonably weighty on the first dimension. There must be some genuine religious practice, which is either obligatory or somewhat central to the claimant's faith, before claims for exemptions can get off the ground. The threshold level of importance that a practice must meet should not be set particularly high, however. Especially in cases of outright conflict, exemptions can be warranted even when the relevant practice is religiously motivated without being based on a central tenet of the claimant's beliefs. Nonetheless, the practice must be "intimately linked to the religion or belief," in the ECtHR's words. ${ }^{73}$ Acts that are "only remotely connected to a precept of faith" fail to reach the level of importance required for an exemption to ever be warranted.

Third, there is also a threshold on the second dimension, but it is at a low level. An individual has a claim for an exemption as long as there is some conflict between the law or rule and her religious practice, such that she bears some (secular) cost by complying with the former consistent with the latter. The interest implicated here need not be particularly important for her to have a claim, although obviously her claim is stronger the more important this interest is. Finally, and more controversially, if a religious claim is strong on either dimension and the competing interest is relatively weak then the exemption should be granted. This is the case even if the claim is relatively weak on the other dimension, assuming the threshold is reached.

\footnotetext{
72 Williamson (n 47) paras 49-52.

${ }^{73}$ Eweida and others (n 4) para 82.
} 
In my view, this final point is fulfilled in both the Sikh motorcycle case and Eweida's case. ${ }^{74}$ Sikhs are religiously obligated to wear the turban, so their claim is weighty on the first dimension. It also reaches the second dimension threshold, since Sikhs can comply only by not riding motorcycles. This clearly isn't a vital interest, but it is nonetheless sufficient for there to be a conflict between the law and the religious practice. The competing state interest, meanwhile, is not hugely strong. Even if laws requiring motorcycle helmets are generally justified, there is no great cost to granting an exemption to them. This is particularly the case if the terms of the exemption include Sikhs bearing responsibility for the costs of any injuries sustained that are greater than they would have been were they wearing a helmet.

Eweida faced the loss of her job due to British Airways' uniform code, so her claim was weighty on the second dimension. Her claim was also weighty enough on the first dimension to make it legitimate: while wearing the necklace was not an obligation, it was something she believed important to her manifestation of her faith. The cross is the central symbol of Christianity, and Eweida considered wearing it to be important to her Christian witness. The competing interest in this case was British Airways' corporate image. While this is not unimportant, it is not strong enough to outweigh Eweida's claim. This is particularly the case given that it is unclear whether BA's image would be particularly damaged by allowing its employees to visibly wear religious jewellery. Indeed, BA changed its uniform policy to allow this, suggesting that it was not essential to their image.

Eweida's case can be helpfully contrasted with that of Shirley Chaplin. Chaplin was an NHS nurse who wanted to wear a crucifix at work. This was not allowed under NHS uniform

\footnotetext{
${ }^{74}$ And also in Ghai's case, as it was understood by the High Court in Ghai v Newcastle City Council [2009] EWHC 978 (Admin). The Court ruled against Ghai, but in my view gave too much weight to the offence that would be caused by 'open air' cremation. The Court of Appeal (n 50) argued that the structures in which Ghai was willing to be cremated counted as buildings under the Cremation Act 1902, so there was in fact no conflict between the law and Ghai's religious practice - his claim had no second-dimension weight, so there was no need for an exemption.
} 
rules. Her claim for an exemption has a similar weight to Eweida's on both dimensions. But the countervailing interest here is much stronger: a reasonable judgment that the crucifix would be a threat to the safety of Chaplin's patients and colleagues. This weightier countervailing interest means that the exemption was rightly denied. My judgment here matches that of the ECtHR, who found in Eweida's favour but rejected Chaplin's claim. ${ }^{75}$

In many cases, of course, an exemption claim is weighty on one or both dimensions and the countervailing interests are also strong. Consider individuals who refuse to work on holy days. The claim for accommodation here might well be based on an obligatory and/or central religious practice, and the cost of not being accommodated might be that the claimant loses their job. This claim is thus weighty on both dimensions. Granting an exemption, however, might be costly and inconvenient for the employer, and unfair to other workers. How strong these countervailing interests are will depend on whether the claimant can make up their hours at another time and whether the employer has sufficient employees that others can cover the work on holy days. ${ }^{76}$ Exemptions are more likely to be justified if arrangements can be made that minimise costs to third parties. Similar comments apply to other cases where the religious claim is weighty on both dimensions but the countervailing interests are also strong, such as Catholic midwives refusing to manage abortion wards and the question of whether a sacred bull infected with bovine tuberculosis can be spared from slaughter. ${ }^{77}$ The correct decision in cases like these will depend upon a context-sensitive judgment of the balance of interests, and the

\footnotetext{
75 ibid paras 89-101.

${ }^{76}$ It is also significant in these cases that the structure of the working week is shaped by the beliefs of the majority, who can therefore more easily combine full-time work with religious practices. It might thus be seen as inegalitarian to deny the exemption. See Bhikhu Parekh, 'Equality in a Multicultural Society', in Jane Franklin (ed), Equality (IPPR 1997) 123-154.

${ }^{77}$ For the midwives case, see Greater Glasgow Health Board v. Doogan \& Anor [2014] UKSC 68. For the bull case, see Surayanda v. The Welsh Ministers [2007] EWCA Civ 893.
} 
extent to which the costs to third parties can be minimised. ${ }^{78}$ The framework developed in this paper still provides essential guidance in these cases, however, since it shows how the vital first step - evaluating the weight of the religious claim - should be undertaken.

\section{THE ADMINISTRABILITY OBJECTION}

A desideratum for theories of religious accommodation is that they can be fairly and consistently applied by both legislators and courts. This was Justice Scalia's main concern in his rejection of the Sherbert test. Scalia argued that courts could not manageably decide questions of sincerity or assess the strength of religious claims and government interests. He "was unwilling to countenance the uncertainties and contextual judgments of any approach that required courts to weigh religious claims against state interests." 79 While highly critical of Scalia's view, Greenawalt also emphasises the importance of administrability. He argues that we should reject the approach that would be best in a world of ideal knowledge and assessment, if it is not administrable in the real world. ${ }^{80}$ Greenawalt endorses the 'weighing approach', but is clear that administrability constrains its content.

Some might object to the account defended in this paper on this basis, arguing that it fails this administrability test. The account calls for complicated judgments across several dimensions. There is always going to be vagueness and uncertainty in determining how 'central' a religious practice is, or how the weight of a religious claim measures up against the weight of

${ }^{78}$ The judgment in Surayanda (ibid) exemplifies this point. The exemption was denied because the alternatives to slaughtering the sacred bull did not adequately eliminate the risks to third parties posed by the spread of bovine tuberculosis (bTB). The court recognized that the exemption claim was weighty, however, since the claimants believed they had a strong religious obligation not to allow the bull to be slaughtered and this obligation was in outright conflict with the policy of slaughtering cattle with a suspected bTB infection.

${ }^{79}$ Greenawalt (n 3) 31.

80 ibid 9-10. 
the countervailing interests. The four claims in the previous section were also rather vague. Different judges could look at the same, or very similar, cases and reasonably reach different conclusions based on the test proposed here. Ultimately, one might claim, this could undermine the rule of law, since cases would be dealt with in inconsistent ways.

This is an important objection, but it is not decisive. I will offer three replies to it here.

First, the law in this area is already shifting, as our understanding of what constitutes reasonable accommodation changes. The approach defended in this paper does not radically differ from the one that appears to be implicit in many rulings in both the USA and Europe, but rather seeks a fuller and richer understanding of what this approach involves.

There are worrying inconsistencies in the present case law. Different courts seem to use somewhat different reasonable accommodation tests, seeing different factors and arguments as relevant to determining whether exemptions should be granted. This is clear from the range of US cases surveyed by Greenawalt. Courts tend to employ a weighing approach and to draw on the kinds of factors highlighted by my view, but use different and inconsistent tests. For example, in Mack v. O'Leary the court stated that a Moorish prisoner who wanted a different 'feast day' to those currently permitted by his prison faced a substantial burden despite this being a non-mandatory part of his faith. ${ }^{81}$ This contrasts with the ruling in Bryant v. Gomez. ${ }^{82}$ Bryant sought 'full Pentecostal services', many elements of which were missing from the interdenominational Christian services permitted at his prison. The Court ruled that he had not established a substantial burden on his religious exercise because he had not shown that those missing elements were mandated by his faith. The fact that his claim was based on nonobligatory parts of his faith was judged to mean that the burden he faced was not substantial, despite Pentecostal worship services being central to his religious practice. This directly contradicts the ruling in Mack v. O'Leary that restrictions on non-mandatory practices can constitute substantial burdens.

\footnotetext{
${ }^{81}$ This prisoner still lost his case. The burden was judged to be outweighed by the countervailing interest. 82 46F.3d 948 [9th Cir. 1995].
} 
European law on religious accommodation is developing fast. In its 2010 judgment on Eweida, the UK Court of Appeal argued that ECtHR jurisprudence on Article 9 did "nothing to advance the claimant's case." 83 This was perhaps true at the time, given the ECtHR's previous endorsement of the free-contract doctrine. ${ }^{84}$ As we have seen, however, the ECtHR ultimately ruled in Eweida's favour, and judged that her Article 9 rights were insufficiently protected within UK law. It is not yet clear how this ruling, along with that on Chaplin, Ladele and McFarlane, will shape future judgments. 85

The key point is that this paper's account fits with the general approach taken by both European and US courts, while seeking to provide much-needed clarity as to precisely what this approach should involve. There is certainly room for reasonable disagreement in applying the account, but it makes clearer which factors should and should not count in determining the weight of religious claims, and helps to show how those factors interact in establishing that weight. Given that courts already apply similar tests, there is no reason to think that the account is not administrable. Indeed, it provides the guidance needed for the rulings of courts to become more consistent, rather than undermining consistency in the way that the administrability objection claims. Further, if this approach was adopted then precedents would develop over

${ }^{83}$ Eweida (n 25) para 22.

84 See Maher (n 28) 223-227, and the summary of ECtHR jurisprudence on religious freedom up to 2010 in Julie Ringelheim, 'Rights, Religion and the Public Sphere: The European Court of Human Rights in Search of a Theory?', in Lorenzo Zucca and Camil Ungureanu (eds), Law, State and Religion in the New Europe: Debates and Dilemmas (CUP 2012) 283-306.

85 For helpful analysis of the significance of the ruling and how it fits into ECtHR's evolving jurisprudence, see Ian Leigh and Andrew Hambler, 'Religious Symbols, Conscience, and the Rights of Others' (2013) 3(1) Oxford Journal of Law and Religion 2-24. 
time, which would help to clarify points of ambiguity and provide a body of case law guiding the future application of the test. This would again allow for a greater consistency in rulings. ${ }^{86}$

A second reply to the administrability objection is that this is an area of law where there will always be difficult judgments and grey areas, unless an implausibly restrictive approach is adopted. The only way to reduce the scope for reasonable disagreement would be to say that exemptions should only ever be granted in a very specific set of cases, such as when the religious claim is based on a strictly obligatory practice that is directly prohibited by law. Such an approach would rule out many of the exemptions that are currently granted, including Sikhs' exemption from wearing motorcycle helmets and carrying kirpans, and the exemptions granted in the landmark Sherbert case and other cases that have followed Sherbert's lead. For those who endorse reasonable accommodation, this should show this narrow approach to be unpalatable.

As Greenawalt writes, "this is one of those domains of law where messiness at the edges, and uneven application, are the regrettable costs of a legal standard that is minimally responsive to the underlying values that matter." 87 If we are to develop an account of reasonable accommodation that adequately protects religious freedom then some room for reasonable disagreement about the correct judgment in particular cases is inevitable.

Third, the account developed here provides much more guidance to courts than existing weighing approaches, and so is superior to them in terms of administrability. For example, Greenawalt ultimately insists that we cannot move beyond the phrase 'substantial burden' in determining the weight of religious claims. He claims that "judges follow a cleaner, more coherent approach if they rely exclusively on the language of 'substantial burden,' recognising that other, more complicated formulations do not aid in resolving the crucial question about the weight of interference with religious exercise." 88 As we have seen, however, simply relying on

\footnotetext{
${ }^{86}$ This point is also made by Nehushtan (n 9) 243. For general discussion of the role of precedent in constitutional rights adjudication, see Alexy (n 18) 373-377.

${ }^{87}$ Greenawalt (n 3) 214.

88 ibid 210.
} 
the vague notion of 'substantial burden' has not led to a clean or coherent approach. Greenawalt is ultimately left relying on his vague intuitive judgments about particular cases, without providing any unified explanation of the way in which he is determining when a burden is 'substantial'. This paper's formulation is certainly more complicated than Greenawalt's, but also aids us in resolving the question of the weight of particular religious claims, contra Greenawalt's assertion.

Those who favour reasonable accommodation should reject blunt approaches that only recognise a 'substantial burden' when a very high threshold is met, and should also reject 'anything goes' approaches that permit any 'good-faith religious claim' to potentially lead to an exemption. We should adopt a 'weighing approach', and thus need guidance as to how to weigh religious claims. Greenawalt acknowledges all of this, but ultimately provides little guidance. This paper has sought to provide such guidance, and this makes its account more easily administrable by lawmakers and courts than Greenawalt's appeal to an apparently unanalysable notion of 'substantial burden'.

There is much room for further philosophical work to specify and clarify my account. The explanation offered in this paper has been sketchy and underdeveloped in places. Further analysis of several of the central concepts, both in the abstract and in relation to concrete cases, is needed in order to sharpen the account. Such work would make the account both more philosophically defensible and easier for legislators and judges to apply.

We should also acknowledge, however, that there might well be a gap between the ideal application of the approach defended here and what can be institutionalised in practice. Constraints of time and information will clearly affect how a regime of reasonable accommodation operates. Sometimes this will mean that judgments about the weight of religious claims, on both of the dimensions discussed in this paper, will be tentative, uncertain, and disputable. 
Nonetheless, the account developed here both formalises ideas implicit in current legal practices and can direct future practices in ways that lead to a more coherent and clear regime of reasonable accommodation. It can thus reinforce the rule of law, rather than undermining it. 